AperTO - Archivio Istituzionale Open Access dell'Università di Torino

Gaseous emissions and nutrient dynamics during composting of swine solid fraction for pellet production

This is a pre print version of the following article:

Original Citation:

Availability:

This version is available http://hdl.handle.net/2318/152138

since $2017-05-25 T 14: 25: 55 Z$

Published version:

DOI:10.12988/ams.2014.46453

Terms of use:

Open Access

Anyone can freely access the full text of works made available as "Open Access". Works made available under a Creative Commons license can be used according to the terms and conditions of said license. Use of all other works requires consent of the right holder (author or publisher) if not exempted from copyright protection by the applicable law. 


\section{(2) \\ UNIVERSITÀ DEGLI STUDI DI TORINO}

This is an author version of the contribution published on:

Applied Mathematical Sciences, Vol. 8, 2014, no. 129, 6459 - 6468 doi: 10.12988/ams.2014.46453

The definitive version is available at:

http://dx.doi.org/10.12988/ams.2014.46453 
Journal's Title, Vol. x, 20xx, no. xx, $x x x$ - xxx

HIKARI Ltd, www.m-hikari.com

http://dx.doi.org/10.12988/

\title{
Gaseous emissions and nutrient dynamics during composting of swine solid fraction for pellet production
}

\author{
Niccolò Pampuro \\ Istituto per le Macchine Agricole e Movimento Terra (IMAMOTER) \\ Consiglio Nazionale delle Ricerche (CNR) \\ Strada delle Cacce, 73. 10135 Torino
}

Elio Dinuccio

Department of Agriculture, Forestry and Food Sciences (DISAFA),

University of Torino

Largo Paolo Braccini 2, 10095 Grugliasco, Italy

Paolo Balsari

Department of Agriculture, Forestry and Food Sciences (DISAFA),

University of Torino

Largo Paolo Braccini 2, 10095 Grugliasco, Italy

\section{Eugenio Cavallo}

Istituto per le Macchine Agricole e Movimento Terra (IMAMOTER)

Consiglio Nazionale delle Ricerche (CNR)

Strada delle Cacce, 73. 10135 Torino, Italy 
Copyright (C) 20xx Niccolò Pampuro, Elio Dinuccio, Paolo Balsari and Eugenio Cavallo. This is an open access article distributed under the Creative Commons Attribution License, which permits unrestricted use, distribution, and reproduction in any medium, provided the original work is properly cited.

\begin{abstract}
In this study, swine solid fraction was composted with the objective to obtain a composted manure with a moisture content between 20 and $40 \%$ - suitable to pelletize. Three identical SF windrows of approximately $4 \mathrm{~m}^{3}$ and $1800 \mathrm{~kg}$ were set up outside, on a concrete pad in an opensided, roofed facility, and composted for a period of 72 days. An evaluation of the composting process and of the final product was made by monitoring process temperature, ammonia $\left(\mathrm{NH}_{3}\right)$ and GHG (carbon dioxide, $\mathrm{CO}_{2}$; methane, $\mathrm{CH}_{4}$; nitrous oxide, $\mathrm{N}_{2} \mathrm{O}$ ) emissions, moisture content, $\mathrm{pH}$, volatile solids (VS), total organic carbon (TOC), total nitrogen (TN) and total ammoniacal nitrogen (TAN). In accordance with the results of the investigation it can be concluded that the composting of swine solid fraction in windrows could be a valuable process to concentrate the nutrients in manure and make it suitable to pelletize. However, appreciable amounts of $\mathrm{CO}_{2}, \mathrm{CH}_{4}$, $\mathrm{N}_{2} \mathrm{O}$ and $\mathrm{NH}_{3}$ emissions were detected. Total emission of the investigated gases recorded during the experimental period were $273 \mathrm{gCO}_{2} \mathrm{kgVS}^{-1}, 3.50 \mathrm{gCH}_{4} \mathrm{kgVS}^{-1}, 19.3 \mathrm{gN}_{2} \mathrm{O} \mathrm{kgTN}{ }^{-1}$ and $87.4 \mathrm{gNH}_{3}$ $\mathrm{kgTN}^{-1}$, respectively. These data can be used to carry out detailed life cycle assessments of GHG emissions from the Italian swine farming.
\end{abstract}

Keywords: ammonia, GHG, manure treatment, pelletization.

\title{
1 Introduction
}

According to estimates [Colonna and Alfano, 2010], pig farms in Italy produce approximately 17 million tons per year of liquid (slurry) manure. Slurry storage followed by land application is the predominate manure management practice due to its simplicity and low cost. However this practice could cause serious environmental problems [Rao et al., 2007] such as nitrate water pollution both in surface and in ground waters, especially in areas classified as vulnerable zones to nitrate in accordance with European Regulation (91/676/CEE).

Several techniques have been developed to manage livestock slurries as cheaply and conveniently as possible and to reduce potential risks of environmental pollution. Among these techniques, solid-liquid separation of slurry is a common practice in Italy. The liquid fraction (LF) is generally used in land applications in areas near the farm, while the solid fraction (SF) is exported to outside farmland areas.

However the low bulk density - less than $500 \mathrm{~kg} \mathrm{~m}^{-3}$ [Pampuro et al., 2012] makes costly to transport SF from production sites to areas where it could be effectively utilized for value-added 
applications such as in soil fertilization. One possible solution to this problem is pelletization of SF [Pampuro et al., 2013]. Pelletization has been shown to increase the biomass bulk density from an initial bulk density of $40-200 \mathrm{~kg} \mathrm{~m}^{-3}$ to a final one more than $800 \mathrm{~kg} \mathrm{~m}^{-3}$ [McMullen et al., 2005]. Thus, pelletization of solid manure could reduce the costs for their transportation, handling and storage [Kaliyan and Vance Morey, 2009].

However the high moisture content (75-80\%) of fresh SF makes it not suitable for pelletization. According to Alemi et al. [2010] the optimal moisture content of SF to be used for pelletization vary between $20 \%$ and $40 \%$. One simple and cheap method to reduce the moisture content of SF is composting, a self-heating, aerobic degradation process of the organic matter. However the emission of harmful gases from composting of livestock manure has been the cause of serious environmental problems such as complaints from residents around farms about odor and destruction of the natural ecosystem by ammonia $\left(\mathrm{NH}_{3}\right)$ and greenhouse gases (GHG) namely methane $\left(\mathrm{CH}_{4}\right)$, carbon dioxide $\left(\mathrm{CO}_{2}\right)$ and nitrous oxide $\left(\mathrm{N}_{2} \mathrm{O}\right)$ [Fukumoto et al., 2003; Dinuccio et al., 2008]. Some studies investigated gaseous emissions and nutrient dynamics during storage of pig solid manure heaps [e.g., Hassouna et al., 2008; Petersen and Sørensen, 2008]. However, to our knowledge, $\mathrm{NH}_{3}$ and $\mathrm{GHG}\left(\mathrm{CO}_{2}, \mathrm{CH}_{4}, \mathrm{~N}_{2} \mathrm{O}\right)$ losses during composting of swine slurry SF for pellet production have had limited investigation. In this study, swine solid fraction was composted in windrows, with the objective to obtain a composted SF with a moisture content between 20 and $40 \%$ - suitable to pelletize. The effect of composting process on i) manure characteristics and ii) $\mathrm{NH}_{3}$ and $\mathrm{GHG}$ emissions was investigated.

\section{Materials and methods}

\subsection{Composting experiment}

The trial was carried out in summer season at the experimental station of the Institute for Agricultural and Earth Moving Machines (IMAMOTER) - Italian National Research Council (CNR) of Turin (northern Italy).

The solid fraction (SF) used for the study was obtained by mechanical solid-liquid separation of fresh swine slurry from a fattening swine farm. Slurry separation was performed using a screw press separator (Chior, mod. COM300/600). Three identical SF windrows of approximately $4 \mathrm{~m}^{3}$ and $1800 \mathrm{~kg}$ were set up outside, on a concrete pad in an open-sided, roofed facility, and composted for a period of 72 days. Each windrow was trapezoidal in shape, about $6 \mathrm{~m}$ in basewidth and $1 \mathrm{~m}$ in height. During the experimental period the windrows were turned six times: at days $7,16,28,35,50$ and 57 . The environmental temperature and temperatures inside the heaps at a depth of $0.2 \mathrm{~m}(\mathrm{~T} 1)$ and $0.6 \mathrm{~m}$ (T2) were continuously recorded using thermocouple sensors (Type K) connected to a multichannel acquisition system (Grant, mod. SQ 1600).

\subsection{Physicochemical parameters}

Representative samples of the tested manure were taken from each windrow at day 0 (beginning of the trial), 7, 16, 28, 35, 50, 57 and 72 (end of the trial). All collected samples were analyzed for moisture content, $\mathrm{pH}$, volatile solids (VS), total organic carbon (TOC), total nitrogen (TN) and total ammoniacal nitrogen (TAN) according to procedures described by Heiermann et al. [2009] and Plochl et al. [2009]. 


\subsection{Gas sampling and analysis}

During the experimental period, $\mathrm{CO}_{2}, \mathrm{CH}_{4}, \mathrm{~N}_{2} \mathrm{O}$ and $\mathrm{NH}_{3}$ emissions were measured simultaneously, from each investigated SF windrow, at least two times a week. Emissions of $\mathrm{CO}_{2}$, $\mathrm{CH}_{4}$ and $\mathrm{N}_{2} \mathrm{O}$ were measured using static closed chamber technique [Livingston and Hutchinson, 1995]. At each sampling time, three polyvinyl chloride chambers (volume $0.021 \mathrm{~m}^{3}$, surface area $0.138 \mathrm{~m}^{2}$ ) were evenly placed over surface of each investigated windrow. Thirty $\mathrm{mL}$ of air was drawn with a plastic syringe from the chamber headspace at 0,10 , and 20 min after chamber placement. All samples were stored in airtight glass vials and analyzed for $\mathrm{CO}_{2}, \mathrm{CH}_{4}$ and $\mathrm{N}_{2} \mathrm{O}$ within $24 \mathrm{~h}$ by gas chromatography (Agilent 7890). $\mathrm{NH}_{3}$ emissions were measured by wind tunnels and the flux measurement procedure described by Dinuccio et al. [2012]. In correspondence of the turning operations, gas $\left[\mathrm{CO}_{2}, \mathrm{CH}_{4}, \mathrm{~N}_{2} \mathrm{O}\right.$ and $\left.\mathrm{NH}_{3}\right]$ emissions rates were evaluated two times: before turning and immediately after turning.

\section{Results and discussion}

\subsection{Temperature development}

The environmental temperature and the temperature profile in the three SF windrows as a function of time is shown in Figure 1. The average recorded environmental temperature was $23.5^{\circ} \mathrm{C}$ (range $18.8^{\circ} \mathrm{C}-27.8^{\circ} \mathrm{C}$ ).

The average temperature of SF windrows rapidly increased to approximately $65^{\circ} \mathrm{C}$ during the first 7 days from their establishment. These high temperatures were maintained during 40 days (Fig. 1) and then slightly decreased to $40^{\circ} \mathrm{C}$, indicating the end of the thermophilic phase [Bernal et al., 2009]. The temperatures increases observed after each turning operation (Fig. 1) were due to the increased levels of oxygen that stimulate microbial activity [Getahun et al., 2012]. During maturation, the temperatures gradually decreased to final values close to ambient air (about $25^{\circ} \mathrm{C}$ ) after 62 days of composting.

\footnotetext{
<<Figure 1, Here >>
}

\subsection{Physicochemical properties of composted SF}

Table 1 shows the characteristics of SF during the composting process. As a consequence of the production of heat during the process, the moisture content of the SF decreased from $73.4 \mathrm{~g}$ $\mathrm{kg}^{-1}$ at the beginning of composting to a value of $34.6 \mathrm{~g} \mathrm{~kg}^{-1}$ found 72 days after composting was initiated. Likewise, TOC content gradually decreased over time due to degradation of organic material [Getahun et al., 2012]. Relative to the fresh SF (day 0), the concentration of TN in the composted manure at the end of the trial (day 72), was 3.61 times higher, while in contrast the TAN content was as much as 18 times lower. Specifically, the concentration of TAN at the end of the process reached a value below $400 \mathrm{mg} \mathrm{kg}^{-1}$ of dry matter (Tab. 1), a fact that indicates that the material has stabilized sufficiently [Zucconi and De Bertoldi, 1987]. 
The pH of SF was generally alkaline (range 7.51-7.96) during composting, because of the accumulation of hydroxyl groups resulting from proteolysis and ammonification [Cáceres et al., 2006]. Mass balance calculations indicated that through the composting process around 1100 liters of water evaporated from each windrow. A total mass reduction of 70 percent was observed.

$<<$ Table 1, Here»>

\subsection{Gas emissions}

In agreement with other published data [e.g., Sommer and Moller, 2000; Dinuccio et al., 2012], the emissions of $\mathrm{CO}_{2}, \mathrm{CH}_{4}, \mathrm{~N}_{2} \mathrm{O}$ and $\mathrm{NH}_{3}$ took place primarily during the thermophilic phase (Fig. 2), when bacterial activity reached its maximum.

$<<$ Figure 2, Here >>

As can be seen in Figure $2 \mathrm{~A}, \mathrm{NH}_{3}$ emissions peaked at the beginning of the trial and then decreased sharply to a negligible value at day 5 . After the first turning operation, $\mathrm{NH}_{3}$ emissions began to increase again and persisted for around 4 days (Fig. 2A). After this time, with the exhaustion of easily degradable materials, the degradation rate decreased and consequently the $\mathrm{NH}_{3}$ emission declined [Jiang et al., 2013]. The cumulative $\mathrm{N}$ losses as $\mathrm{NH}_{3}$ (Tab. 2) recorded over the experimental period were on average about $25 \%$ higher than the overall losses (6.5-7.3\%) from the initial TN content recorded by Hassouna et al. [2008] during uncovered storage of turned swine solid manure heaps. The highest $\mathrm{NH}_{3}$ losses observed in this study might be explained by the greater TAN content (Tab. 1) of fresh SF and greater surface area-to-volume ratio (3.6) of the windrows, both of which may increase $\mathrm{NH}_{3}$ emissions [Bernal et al. 2009].

$<<$ Table 2, Here >>

The production of $\mathrm{N}_{2} \mathrm{O}$ (Fig. 2B) indicated that during composting, incomplete nitrification/denitrification processes - that normally convert $\mathrm{NH}_{4}$ into $\mathrm{N}_{2}$, a non-polluting gas occurred. Turning the material produced a significant effect on $\mathrm{N}_{2} \mathrm{O}$ emission, because $\mathrm{NO}_{2}{ }^{-} / \mathrm{NO}_{3}{ }^{-}$ produced in $\mathrm{O}_{2}$ sufficient region was transferred to $\mathrm{O}_{2}$ deficient region, thereby promoting $\mathrm{N}_{2} \mathrm{O}$ production by denitrification process [Fukumoto et al., 2003 and Yang et al., 2013]. Cumulative losses of initial total $\mathrm{N}$ content as $\mathrm{N}_{2} \mathrm{O}$ were close to $2 \%$ (Tab. 2), up to $40 \%$ lower than those (3.2$2.5 \%$ of initial $\mathrm{N}$ content in manure) reported in the study of Hassouna et al. [2008]. As expected, the $\mathrm{CH}_{4}$ emission rate decreased immediately after turning operations as a result of the adequate aeration of the pile (Fig. 2C). However, in the interval between turnings, the intense aerobic activity determined a decrease of oxygen concentration that promoted anaerobic conditions and hence the production of methane [Chiumenti et al., 2007]. The $\mathrm{CO}_{2}$ emissions were also influenced by turning (Fig. $2 \mathrm{C}$ ). The average daily $\mathrm{CO}_{2}$ emissions reached a maximum value of 13.2 $\mathrm{g} \mathrm{m}^{-2} \mathrm{~h}$ at the 11th day. After 20 days from the beginning of the test the production of $\mathrm{CO}_{2}$ decreased sharply due to the lower availability of easily fermentable organic matter [Chiumenti et 
al., 2007]. Total $\mathrm{CO}_{2}$ and $\mathrm{CH}_{4}$ emissions represented, respectively, a loss of $27.3 \%$ and $0.35 \%$ of the initial VS content of the manure (Tab. 2), values that agreed well with those reported by Hansen et al. [2006] from storage of uncovered swine SF piles.

\section{Conclusions}

In accordance with the results of the investigation it can be concluded that the composting of swine solid fraction in windrows could be a valuable process to concentrate the nutrients in manure and make it suitable to pelletize. However, appreciable amounts of $\mathrm{CO}_{2}, \mathrm{CH}_{4}, \mathrm{~N}_{2} \mathrm{O}$ and $\mathrm{NH}_{3}$ emissions were detected. Total emission of the investigated gases recorded during the experimental period were $273 \mathrm{gCO}_{2} \mathrm{kgVS}^{-1}, 3.50 \mathrm{gCH}_{4} \mathrm{kgVS}^{-1}, 19.3 \mathrm{gN}_{2} \mathrm{O} \mathrm{kgTN}{ }^{-1}$ and $87.4 \mathrm{gNH}_{3}$ $\mathrm{kgTN}^{-1}$, respectively. These data can be used to carry out detailed life cycle assessments of GHG emissions from the Italian swine sector.

Acknowledgements. This work was carried out within the framework of the "FITRAREF" project, funded by the Italian Ministry of Agriculture and Forestry (Call OIGA, 2009).

\section{References}

[1] H. Alemi, M.H. Kianmehr and A.M. Borghaee, Effect of pellet processing of fertilization on slow-release nitrogen in soil, Asian Journal of Plant Sciences, 9(2) (2010), 74-80.

[2] M.P. Bernal, J.A. Alburquerque and R. Moral, Composting of animal manures and chemical criteria for compost maturity assessment. A review, Bioresource Technology, 100 (2009), 5444-5453.

[3] R. Cáceres, X. Flotats and O. Marfà, Changes in the chemical and physicochemical properties of the solid fraction of cattle slurry during composting using different aeration strategies, Waste Management, 26 (2006), 1081-1091.

[4] A. Chiumenti, F. Da Borso, T. Rodar and R. Chiumenti, 2007. Swine manure composting by means of experimental turning equipment, Waste Management, 27 (2007), 1774-1782.

[5] N. Colonna and V. Alfano, Quanto biogas si può produrre in Italia, L'Informatore Agrario, 11, Supplemento Energia Rinnovabile, (2010), 13-17. 
[6] E. Dinuccio, W. Berg and P. Balsari, Gaseous emissions from the storage of untreated slurries and the fractions obtained after mechanical separation, Atmospheric Environment, 42 (2008), 2448-2459.

[7] E. Dinuccio, F. Gioelli, P. Balsari and N. Dorno, Ammonia losses from the storage and application of raw and chemo-mechanically separated slurry, Agriculture, Ecosystems \& Environment, 153 (2012), 16-23.

[8] Y. Fukumoto, T. Osada, D. Hanajima, and K. Haga, Patterns and quantities of $\mathrm{NH}_{3}$ and $\mathrm{CH}_{4}$ emissions during swine manure composting without forced aeration-effect of compost pile scale, Bioresource Technology, 89 (2003), 109-114.

[9] T. Getahun, A. Nigusie, T. Entele, T. Van Gerven and B. Van der Bruggen, Effect of turning frequencies on composting biodegradable municipal solid waste quality, Resources, Conservation and Recycling, 65 (2012), 79-84.

[10] M.N. Hansen, K. Henriksen, S.G. Sommer, Observations of production and emission of greenhouse gases and ammonia during storage of solids separated from pig slurry: Effects of covering, Atmospheric Environment, 40 (2006), 4172-4181.

[11] M. Hassouna, S. Espagnol, P. Robin, J-M. Paillat, P. Levasseur, Y. Li, Monitoring $\mathrm{NH}_{3}, \mathrm{~N}_{2} \mathrm{O}, \mathrm{CO}_{2}$ and $\mathrm{CH}_{4}$ Emissions During Pig Solid Manure Storage - Effect of Turning, Compost Science \& Utilization, 16:4 (2008), 267-274.

[12] M. Heiermann, M. Plochl, B. Linke, H. Schelle and H. Hermann, Biogas Crops - Part I: Specifications and Suitability of Field Crops for Anaerobic Digestion, Agricultural Engineering International: the CIGR Ejournal, Manuscript 1087 (2009), vol XI.

[13] T. Jiang, F. Schuchardt, G.H. Li, R. Guo, and Y.M. Luo, Gaseous emission during the composting of pig feces from Chinese, Chemosphere, 90 (2013), 1545-1551.

[14] N. Kaliyan and R. Vance Morey, Factors affecting strength and durability of densified biomass products, Biomass \& Bioenergy, 33 (2009), 337-359.

[15] G.P. Livingston, G.L. Hutchinson, Enclosed-based measurement of trace gas exchange: Applications and sources of error. In P.A. Matson and R.C. Harriss (ed.) Biogenic trace gases: Measuring emissions from soil and water. Methods in ecology series (1995), Blackwell Science, Cambridge, UK.

[16] J. McMullen, O.O. Fasina, C.W. Wood and Y. Feg, Storage and handling characteristics of pellets from poultry litter, Applied Engineering in Agriculture, 21 (2005), 645-651.

[17] N. Pampuro, A. Facello and E. Cavallo, Density-pressure relationship in densification of swine solid fraction, Proc. International Conference of Agricultural Engineering, Valencia (Spain), July 8-12, 2012. 
[18] N. Pampuro, A. Facello and E. Cavallo, Pressure and specific Energy requirements for densification of compost derived from swine solid fraction, Spanish Journal of Agricultural Research, 11(3), (2013), 678-684.

[19] J. Petersen, P. Sørensen, Loss of nitrogen and carbon during storage of the fibrous fraction of separated pig slurry and influence on nitrogen availability. J. Agric. Sci., 146 (2008), 403-413.

[20] M. Plochl, A. Hilse, M. Heiermann, T. Suarez, J. Budde and A. Prochnow, Hydrolytic enzymes improve fluidity of biogas feedstock, Agricultural Engineering International: the CIGR Ejournal, Manuscript 1529, (2009), vol IX.

[21] J.R. Rao, M. Watabe, T.A. Stewart, B.C. Millar and J.E. Moore, Pelleted organo-mineral fertilizers from composted pig slurry solids. animal wastes and spent mushroom compost for amenity grassland, Waste Management, 27 (2007), 1117-1128.

[22] S.G. Sommer and H.B. Moller, Emission of greenhouse gases during composting of deep litter from pig production - effect of straw content, Journal of Agricultural Science, 134 (2000), 327-335.

[23] F. Yang, G.X. Li, Q.Y. Yang and W.H. Luo, Effect of bulking agents on maturity and gaseous emissions during kitchen waste composting, Chemosphere, 93 (2013), 1393-1399.

[24] F. Zucconi and M. De Bertoldi, Compost specifications for the production and characterization of compost from municipal solid waste. In: De Bertoldi, M., Ferranti, M.P., L'Hermite, P., Zucconi, F. (Eds.), Compost: Production, Quality and Use. Elsevier, Barking, (1987), 30-50. 


\section{FIGURES AND TABLES}




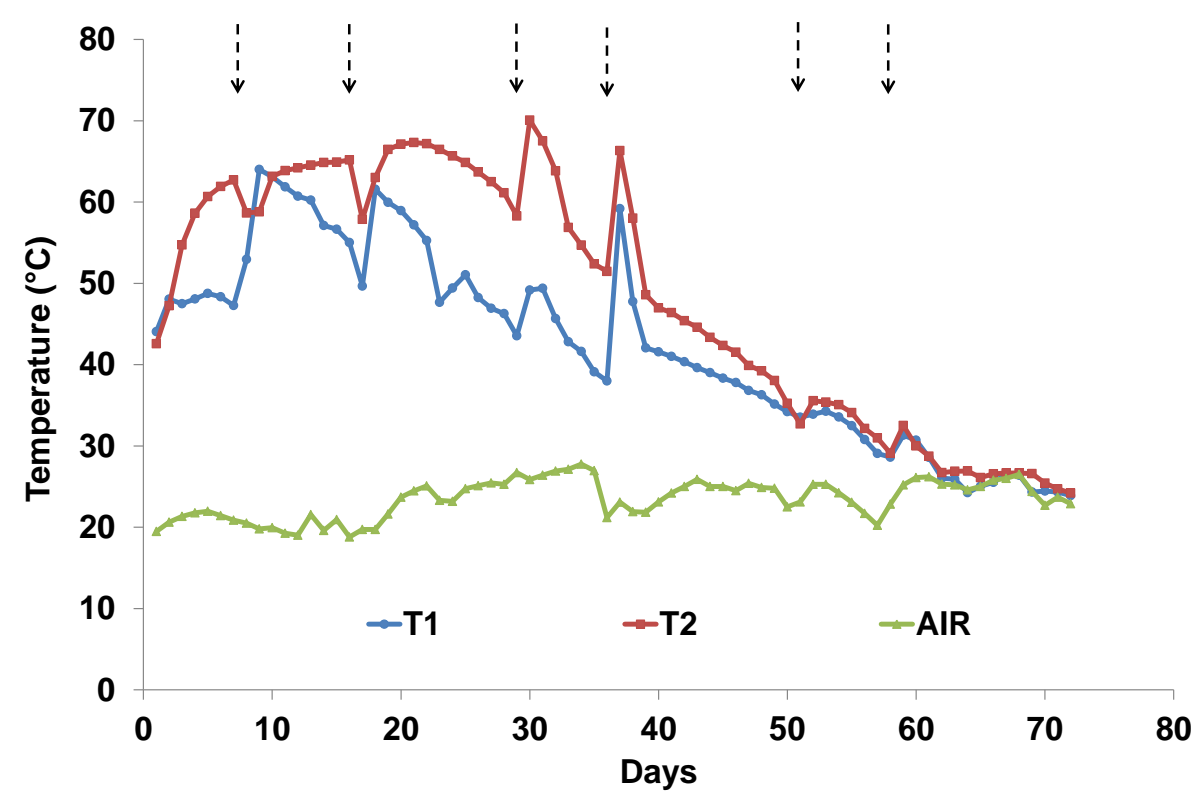

Fig 1: Average environmental temperature and temperatures development at a depth of $0.2 \mathrm{~m}$ (T1) and $0.6 \mathrm{~m}$ (T2) inside the windrows ( $\mathrm{n}=3$ ).

Arrows mark time of turning. 

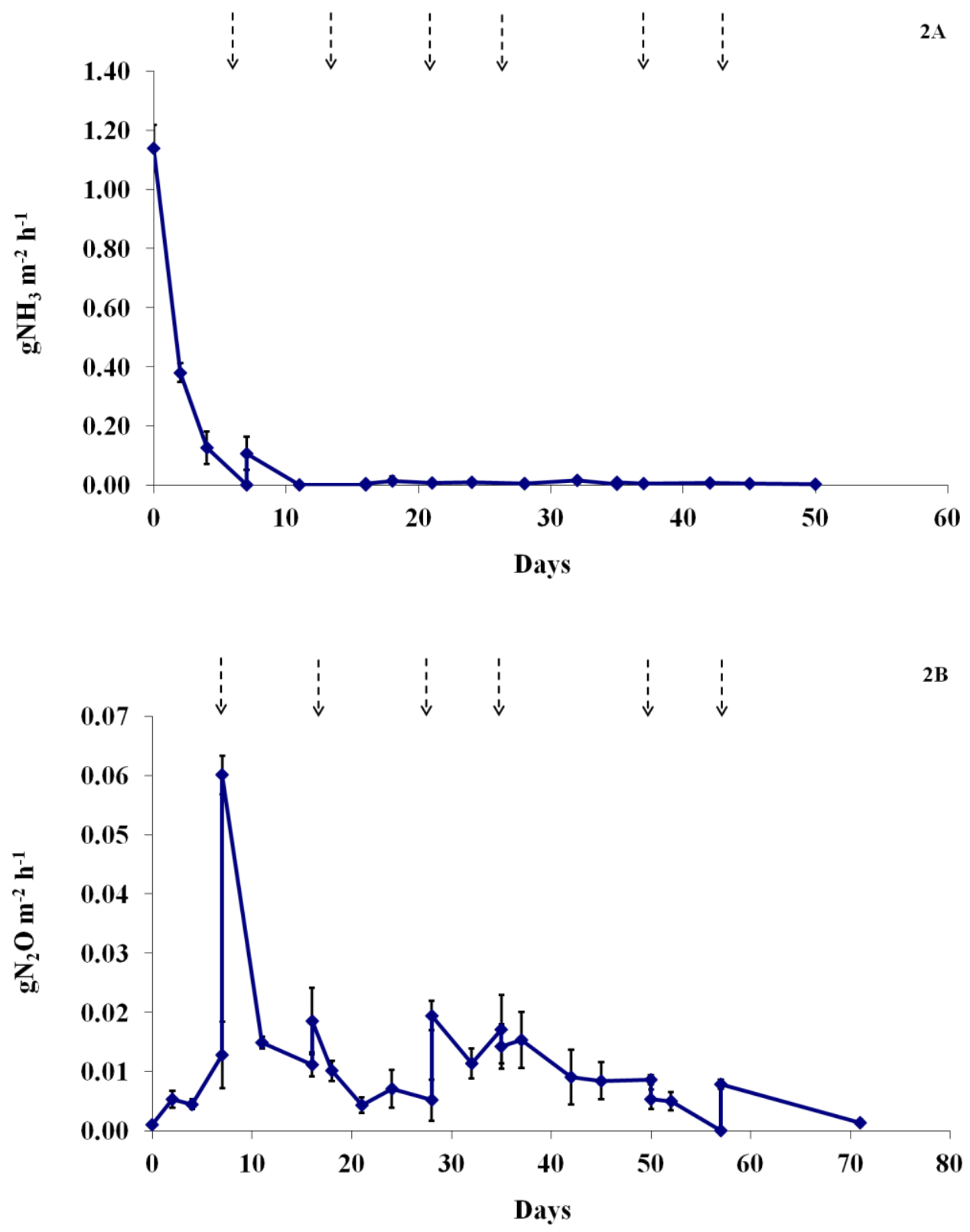

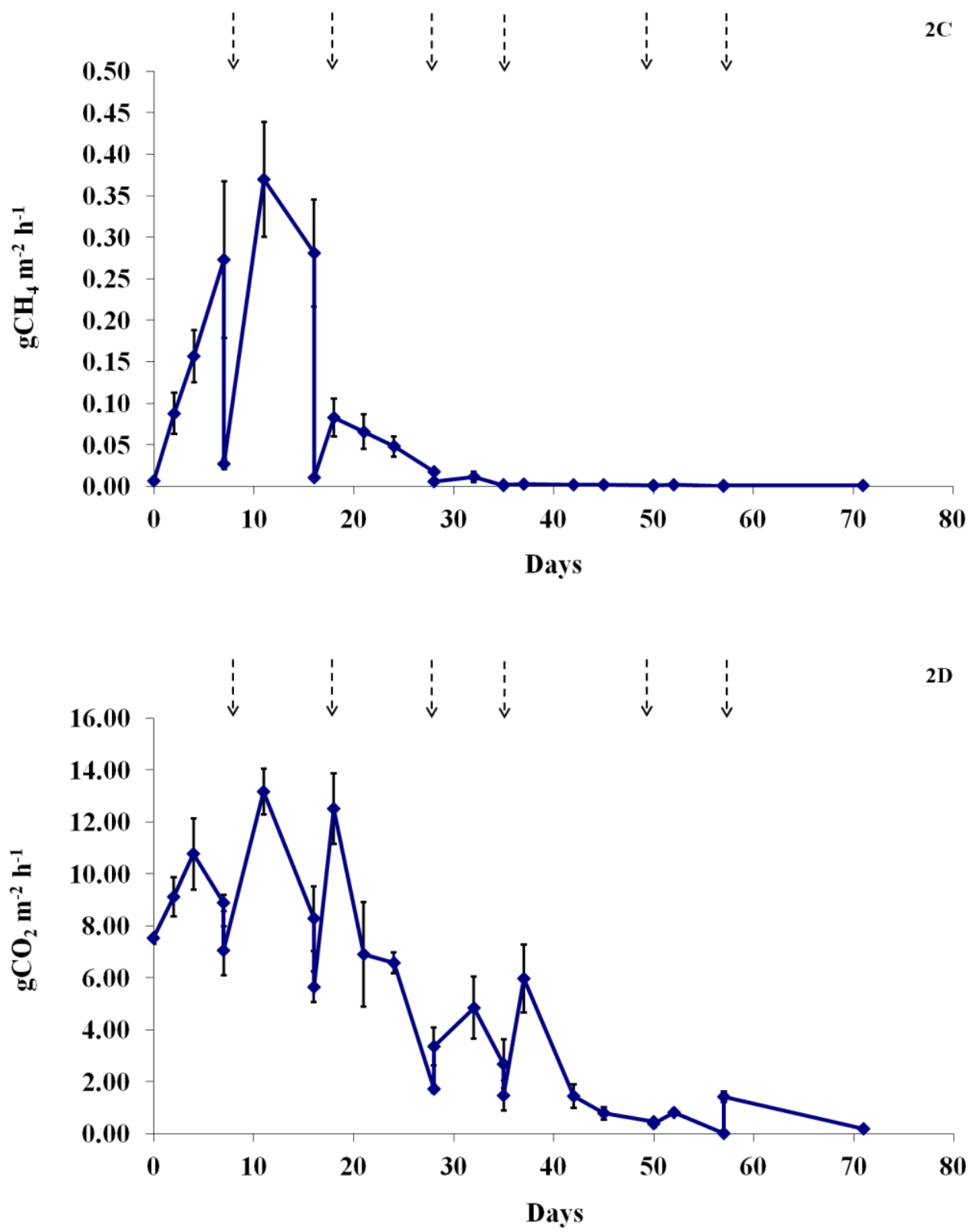

Fig 2: $\mathrm{NH}_{3}(A), \mathrm{N}_{2} \mathrm{O}(B), \mathrm{CH}_{4}(C)$ and $\mathrm{CO}_{2}$ (D) emission fluxes ( $\left.\mathrm{n}=3\right)$ during the composting of swine solid fraction.

Error bars indicate standard error $(n=3)$.

Arrows mark time of turning. 
Tab 1: Physical-chemical characteristics of SF during the composting process. Mean value and standard error (in parentheses) of 3 replicates.

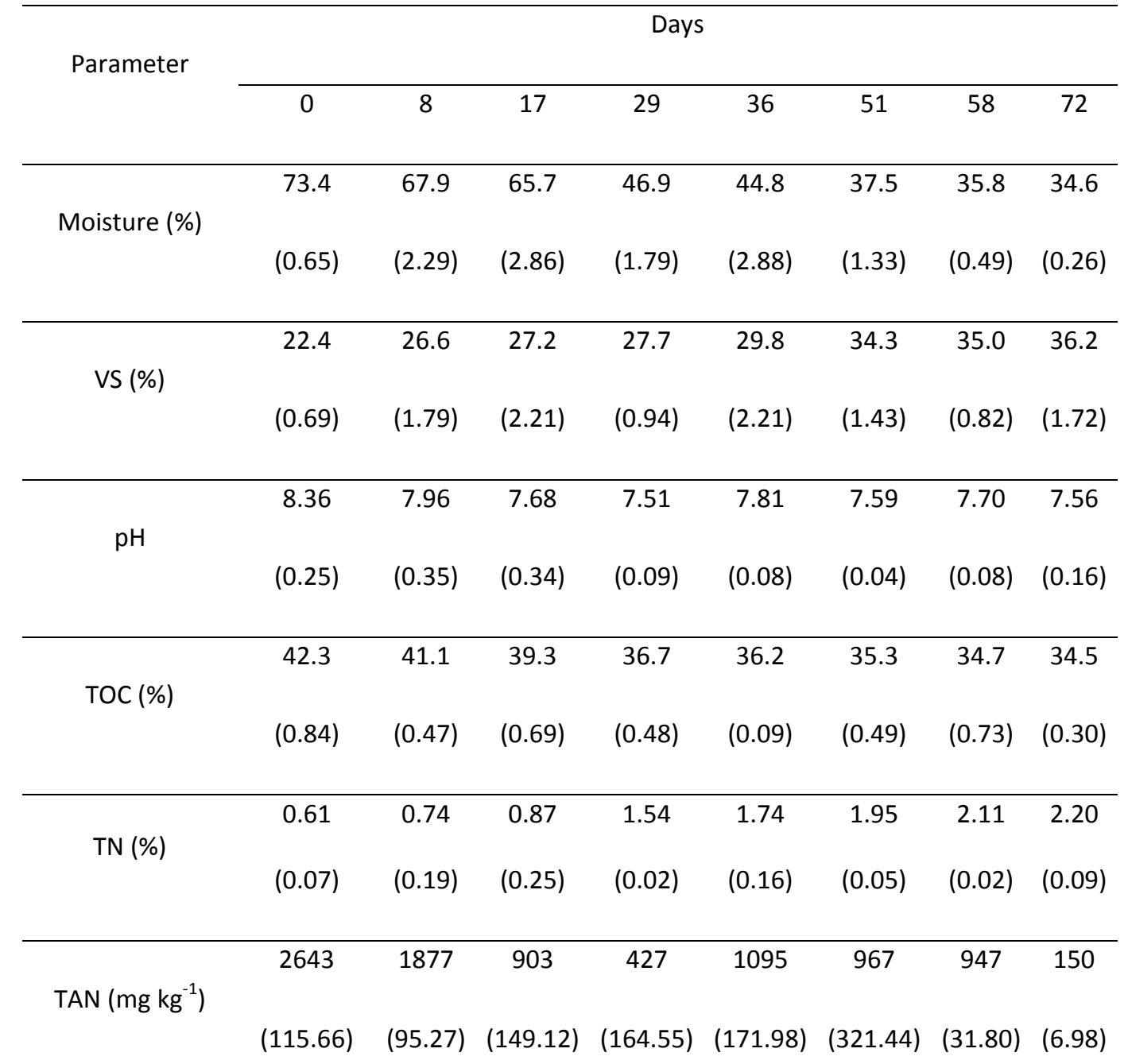


Tab 2: Cumulative emissions of $\mathrm{NH}_{3}, \mathrm{CH}_{4}, \mathrm{CO}_{2}$ and $\mathrm{N}_{2} \mathrm{O}$. Mean value and standard error (in parentheses) of 3 replicates.

\begin{tabular}{|c|c|c|c|}
\hline $\begin{array}{c}\mathrm{NH}_{3} \\
\text { (\%TN) }\end{array}$ & $\begin{array}{c}\mathrm{CH}_{4} \\
\text { (\%VS) }\end{array}$ & $\begin{array}{c}\mathrm{CO}_{2} \\
\text { (\%VS) }\end{array}$ & $\begin{array}{c}\mathrm{N}_{2} \mathrm{O} \\
(\% \mathrm{TN})\end{array}$ \\
\hline 8.74 & 0.35 & 27.3 & 1.93 \\
\hline$(0.55)$ & $(0.01)$ & $(2.32)$ & $(0.17)$ \\
\hline
\end{tabular}

Received: Month xx, 20xx 